\title{
Marine richness and gradients at Deception Island, Antarctica
}

\author{
DAVID K.A. BARNES*, KATRIN LINSE, PETER ENDERLEIN, DAN SMALE, \\ KEIRON P.P. FRASER and MATT BROWN \\ British Antarctic Survey, NERC, High Cross, Madingley Road, Cambridge CB3 OET, UK \\ *dkab@bas.ac.uk
}

\begin{abstract}
Studies of the recovery of the fauna following the 1967-70 eruptions at Deception Island, South Shetland Islands, have made it one of the best-studied marine sites of the Southern Ocean for biodiversity. Using SCUBA we surveyed the mega- and macro-epifauna of its subtidal zones in the entrance (Neptune's Bellows), immediately inside the caldera (Whaler's Bay) and well within the caldera (Fumarole Bay). Richness declined from 10 phyla, 13 classes and 35 species at Neptune's Bellows to three phyla, four classes and five species in Whaler's Bay and just two phyla, classes and species at Fumarole Bay. Amongst the 35 species we found at Neptune's Bellows, 14 were previously unrecorded from Deception Island. Despite many ship visits and amongst the warmest sea temperatures in the Southern Ocean, the Non Indigenous Species (NIS) algae were not found in our survey. Deception Island has been recolonized considerably since the recent eruptions, but many taxa are still very poorly represented and the colonizers present are mainly those with planktotrophic larvae. Examination of the literature revealed that to date 163 named marine species have been found within the caldera as well as at least 50 more morphospecies, which are yet to be identified. Species accumulation has consistently increased across eight recent samples reported and the number of species reported there is likely to reach 300 when taxa such as the nematodes are identified to species level. This represents a first meaningful total species estimate for an Antarctic marine area and, as the site is comparatively impoverished, indicates how rich the surrounding Antarctic shelf must be.
\end{abstract}

Received 19 July 2007, accepted 11 September 2007

Key words: benthos, recolonization, South Shetland Islands, volcano, recovery

\section{Introduction}

With one of the highest concentrations of scientific research stations anywhere in the world, the waters around the bays of the South Shetland Islands are probably the most well studied shelf areas in Antarctica. A young volcano in this archipelago, Deception Island, erupted before 1843, in the 1920s and then again in 1967, 1969 and 1970 (Elderfield 1972). Expeditions to sample the benthos of the seabed in and around the caldera from years to decades after the eruption (Gallardo \& Castillo 1968, 1970, Gallardo et al. 1975, 1977, Retamal et al. 1982, Arnaud et al. 1998, Cranmer et al. 2003, Lovell \& Trego 2003) have created by far the most documented impact and recolonization of an eruption in polar seas. Gallardo et al. (1977) reported abundance values were still relatively low three years after the last of these eruptions but had increased by $2-3$ orders of magnitude to tens to hundreds of individuals per square metre. The opportunistic species Echiurus antarcticus (Echiura) invaded in 1972 and by 11 years after the last eruption some typical fauna, the echinoderms Odontaster validus, Ophionotus victoriae and Sterechinus neumayeri,

This publication is dedicated to the memory of Dr Helen R. Wilcock for whom to visit Antarctica was a lifelong dream. had recolonized the site (Retamal et al. 1982). Subsequently studies revealed the megabenthic fauna inside the caldera is now dominated by $O$. victoriae, $S$. neumayeri, $O$. validus, the nemerteans Parbolasia corrugatus and the shrimp Notocrangon antarcticus (Arnaud et al. 1998, Cranmer et al. 2003, Lovell \& Trego 2003). Sampling throughout the year, Lovell \& Trego (2003) recently reported a total of 13 phyla, 16 classes and 68 'species' from Deception Island. They also showed that individual samples typically contained less than half of these species and only $\sim 26 \%$ and $19 \%$ of the species richness found in similar samples from Livingston and King George islands.

Although many plant and a few animal non-indigenous species (NIS) have established on islands south of the Polar Front (Frenot et al. 2005), the situation has seemingly been different in the sea (Barnes et al. 2006). Deception Island has been and still is a centre of interest for NIS establishment in Antarctica. It had become the most southerly site for establishment of an NIS plant (a Poa species), although this was wiped out by the eruptions (Smith 1996). However, a decade ago an invasive NIS alga Enteromorpha intestinalis (L.) was discovered to have become established in the shallows (Clayton et al. 1997), and recent evidence suggests several more NIS algae may be present (C. Wienke, personal communication 2007). Adults of one (Tavares \& Melo 2004) 


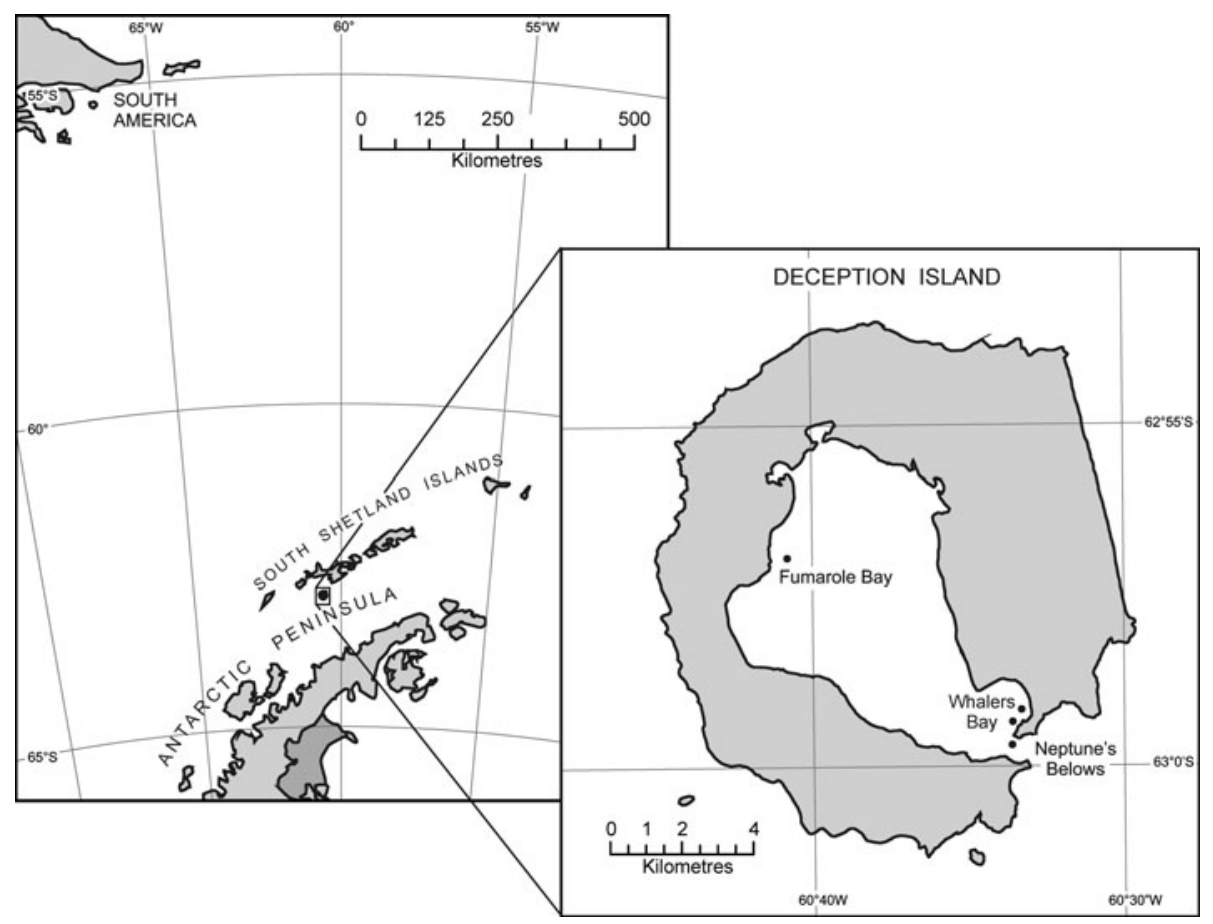

Fig. 1. The position of Deception Island in the Southern Ocean and the location of the sample sites (filled circles) in the caldera (Port Foster).

Table I. Species recorded in the current study during SCUBA surveys at sites in Deception Island, Antarctica.

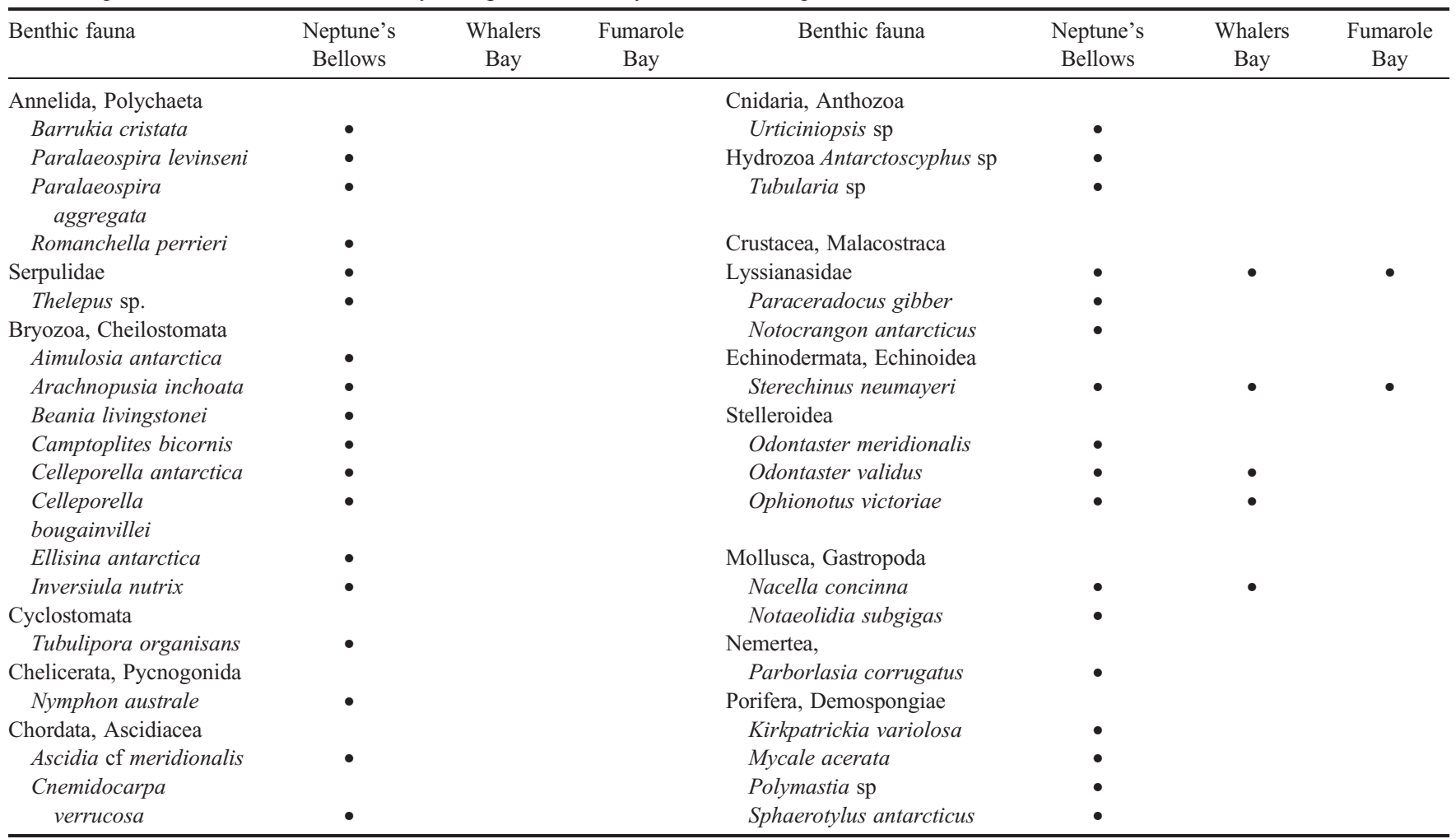


a

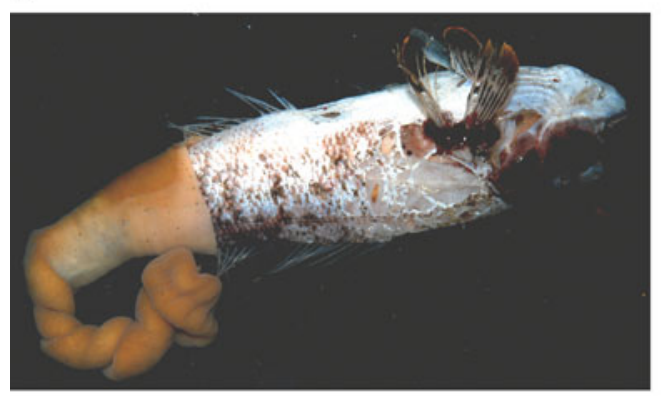

b

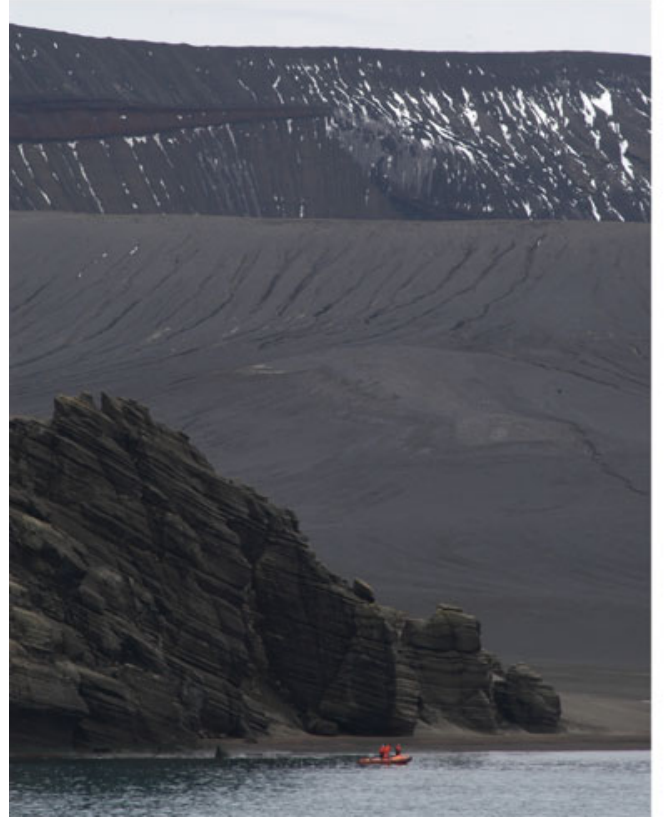

C

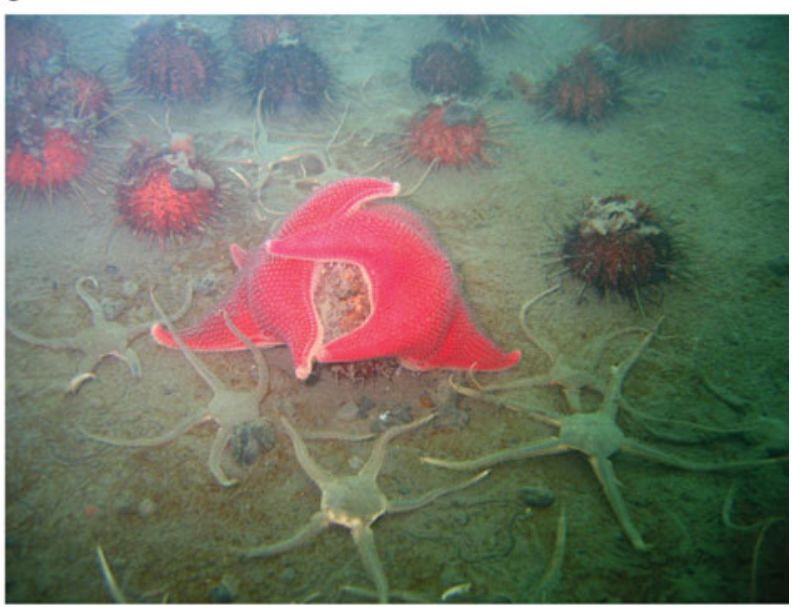

d

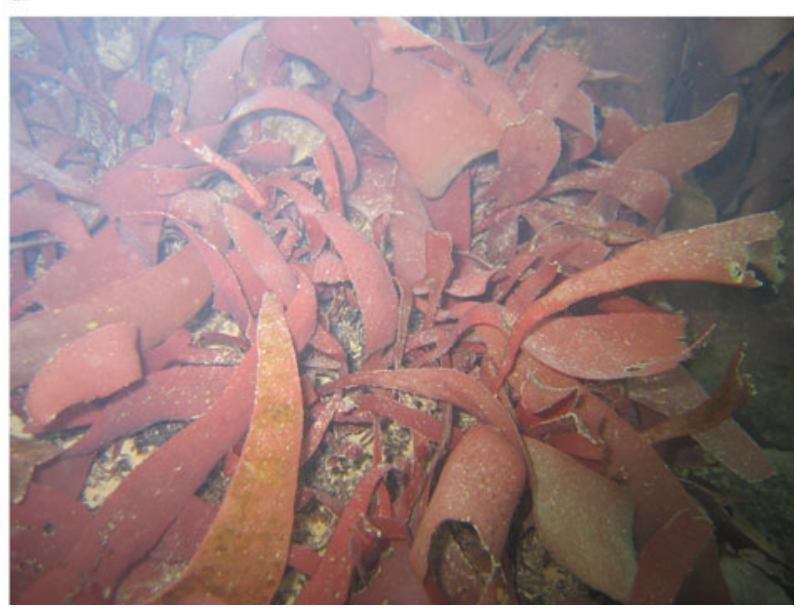

Fig. 2. Species and scenes at Deception Island, including a. one of the most common predator/scavengers at Neptune's Bellows, the nemertean worm Parbolasia corrugatus shown swallowing a dead fish, b. above surface at Fumarole Bay, and below surface at $8-12 \mathrm{~m}$ depth at c. Whaler's Bay and d. Fumarole Bay, Deception Island. The benthic species shown at Whaler's Bay are the echinoid Sterechinus neumayeri, the asteroid Odontaster validus and the ophiuroid Ophionotus victoriae.

and larvae of other NIS decapod crustaceans (Thatje \& Fuentes 2003) were found in single samples elsewhere in the South Shetland islands, but to date no NIS animals are known to have established anywhere in the Southern Ocean.

At shelf depths around and inside Deception Island there is now a good record of benthic taxa present. This record effectively documents recovery over the decades since the eruptions. Compared to nearby islands Deception Island is clearly depauperate at depth (Lovell \& Trego 2003). However, the fauna of the shallow subtidal (and intertidal) zone at Deception Island are relatively poorly known despite the area becoming a recognized site for cruise ship recreational SCUBA diving (Trotter 2006). As well as being useful for studies of long-term recolonization, periodic surveys of the fauna of the shallows at Deception Island are important as it is a likely site for the invasion of NIS. The shallows of Deception Island are one of the warmest sites (albeit patchily) in the Southern Ocean and the caldera is one of the more visited sites by ships coming from temperate ports (e.g. Ushuaia, Argentina). Ship borne transport is probably how NIS algae arrived at Deception Island (Clayton et al. 1997) and many NIS fauna were documented as arriving at Macquarie Island on a single vessel (Lewis et al. 2006). The current study aimed to generate an inventory of the macro- and mega-benthos of the shallow subtidal at Deception Island from the entrance to far inside the caldera, and to include (for the first time) cryptofauna. Particular effort was made to search for possible NIS and to identify fauna to the highest possible resolution.

\section{Method}

Study sites

The study sites were in the drowned caldera of Deception Island, an active volcano in the South Shetland Islands at 
Table II. Marine species recorded from Deception Island up to March 2007. Data from species recorded by Chevreux 1913, Gallardo et al. 1977, Moyano 1978, Retamal et al. 1982, Olaso et al. 1997, Child 1994, 1995a, 1995b, San Martin et al. 2000, Crammer et al. 2003, SOMBASE - Griffiths et al. 2003, 2008, Lovell \& Trego 2003, San Vicente et al. 2007, BAS unpublished data and current study. Some species have been recorded under previous names $(*)$ and some records $\left(^{\dagger}\right)$ have been considered unlikely.

\section{Annelida}

Polychaeta

Aglaophamus macroura (Schmarda 1861)

Aglaophamus ornatus Hartman, 1967

Aglaophamus trissophyllus (Grube, 1877)

Amage sculpta Ehlers, 1908

Ampharete kerguelensis McIntosh, 1885

Amphicteis gunneri (Sars, 1835)

Amphitrite kerguelensis McIntosh, 1876

Austrolaenilla setobarba (Monro, 1930)

Austrophyllum monroi Hartman, 1964

Autolytus charcoti Gravier, 1906

Axiothella antarctica Monro, 1930

Barrukia cristata (Willey, 1902)

Brada villosa (Rathke, 1843)

Chaetozone setosa Malmgren, 1867

Dovillea $\mathrm{sp}$

Eclysippe sp

Euchone pallida Ehlers, 1908

Flabelligera pennigera Ehlers, 1908

Flabelligera mundata Gravier, 1906

Galathowenia wilsoni Blake, 1984

Haploscoloplos kerguelensis (McIntosh, 1885)

Lanicides bilobata (Grube 1877)

Leaena antarctica McIntosh, 1885

Leaena collaris Hessle, 1917

Leaena wandelensis Gravier 1907

Leitoscoloplos kerguelensis (McIntosh, 1885)

Lumbrineris kerguelensis Grube 1878

Lysilla loveni Malmgren, 1866

Maldane sarsi Malmgren, 1865

Mesospio moorei Gravier 1911

Neanthes kerguelensis (McIntosh 1885)

Notomastus latericeus Sars, 1851

Ophelina breviata (Ehlers, 1913)

Perkinsiana $\mathrm{sp}$
Palpiphitime lobifera (Oug, 1978)

Paralaeospira levinseni (Caullery \& Esnil, 1897)

Paralaeospira aggregatus (Caullery \& Esnil, 1897)

Pionosyllis kerguelensis (McIntosh, 1885)

Pista cristata (Muller, 1776)

Proclea glabrolimbata Hessle, 1917

Romanchella perrieri (Caullery \& Esnil, 1897)

Scalibregma inflatum Rathke, 1843

Schistomeringos sp

Sosanopsis kerguelensis Monro, 1939

Spiophanes tcherniai Fauvel, 1950

Travisia kerguelensis Monro 1930

Tauberia gracilis (Tauber, 1879)

Terebella ehlersi Gravier, 1907

Tharyx cincinnatus (Ehlers, 1908)

Thelepides koehleri Gravier, 1911

Thelepus cicinnatus (Fabricius 1780)

\section{Bryozoa}

Cheilostomata

Aimulosia antarctica (Powell 1967)

Arachnopusia inchoata Hayward \& Torpe 1988

Arachnopusia monoceros $^{\dagger}$ (Busk 1854)

Beania errecta* Waters 1904

Camptoplites bicornis (Busk 1884)

Camptoplites giganteus (Kluge 1914)

Carbasea ovoidea Busk 1852

Cellaria diversa* Livingstone 1928

Cellarinella watersi $^{*}$ Calvet 1909

Celleporella antarctica Moyano \& Gordon 1980

Celleporella bougainvillei* (d'Orbigny 1842)

Cornucopina polymorpha (Kluge 1914)

Ellisina antarctica Hastings 1945

Escharella mamillata* Hayward \& Thorpe 1987

Escharoides praesita (Waters 1904)
Escharoidea tridens (Calvet 1909)

Exochella longirostris Jullien 1888

Harpecia spinosissima* (Calvet 1904)

Himantozoum antarcticum (Calvet 1909)

Hippadanella inerma* (Calvet 1909)

Inversiula nutrix Jullien 1888

Isosecuriflustra tenuis* (Kluge 1914)

Isosecuriflustra thysanica* (Moyano 1972)

Klugeflustra antarctica* (Hastings 1943)

Melicerita latilaminata Rogick 1956

Notoplites drygalski (Kluge 1914)

Osthimosia malingae* Hayward 1992

O. mariae* Hayward 1992

O. milleporoides (Calvet 1909)

Romancheina asymmetrica Moyano 1975

Smittina rogickae* Hayward \& Taylor 1984

Toretocheilum absidatum Rogick 1960

Cyclostomata

Idmidronea atlantica Johnston, 1847

Patinella sp

Tubulipora organisans d'Orbigny 1847

Tubulipora tubigera (Busk, 1886)

\section{Chelicerata}

Pycnogonida

Ammothea carolinensis Leach, 1814

Austropallene cornigera (Mobiuis, 1902)

Austroraptus juvenilis Calman, 1915

Colossendeis megalonyx Hoek, 1881

Pallenopsis patagonica (Hoek, 1881)

Nymphon australe Hodgson, 1902

\section{Chordata}

Ascidiacea

Ascidia meridionalis Herdman, 1880

Bathypera sp the northern end of the Antarctic Peninsula (Fig. 1). Where part of the caldera wall collapsed there is a narrow sill $11 \mathrm{~m}$ deep connecting the marine lake inside with the waters of the Bransfield Strait. Fast ice seasonally covers the area, Port Foster, inside the caldera (Smith et al. 2003). At the time of our SCUBA survey, the first site at the entrance, Neptune's Bellows, was characterized by boulder, cobbles and pebbles with patchily abundant macroalgae. Current velocities at peak flow were estimated to be in excess of $1 \mathrm{~m} \mathrm{~s}^{-1}$ and the sea surface temperature was about $1.5^{\circ} \mathrm{C}$. The two sites dived in Whalers Bay had the occasional boulder or piles of cobbles but were typically steeply sloping gravel and coarse volcanic sands and muds. There was negligible current and the sea surface temperature was $\sim 2{ }^{\circ} \mathrm{C}$. Digital temperature gauges worn by divers indicated subsurface (to $12 \mathrm{~m}$ depth) temperatures differed little from those on the surface. The final site, further inside the caldera, at Fumarole Bay was also characterized by gently sloping coarse volcanic sands and muds. As with the Whalers Bay sites, Fumarole Bay also had negligible current but it was warmer at $4^{\circ} \mathrm{C}$, and one near surface measurement was as high as $20^{\circ} \mathrm{C}$. Visibility on all dives was $c .6 \mathrm{~m}$.

\section{SCUBA survey}

In each area divers swam two transects of $\sim 30 \mathrm{~m}$ parallel to the shore, one at 11-12 $\mathrm{m}$ depth then one at $\sim 4 \mathrm{~m}$, except for Fumarole Bay where no more than $6 \mathrm{~m}$ was reached. These depths were selected as initial observations suggested they seemed to be faunistically different. Approximately two metres each side of this belt transect were surveyed for mega-, macro- and crypto-benthos. Transect lengths were estimated by both divers and by personnel at the surface from furthest position of bubble emergence relative to entry point. All fauna encountered were identified in situ or collected, and the most numerically dominant taxa were noted. A Canon Powershot 
Table II. (continued) Marine species recorded from Deception Island up to March 2007. Data from species recorded by Chevreux 1913, Gallardo et al. 1977, Moyano 1978, Retamal et al. 1982, Olaso et al. 1997, Child 1994, 1995a, 1995b, San Martin et al. 2000, Crammer et al. 2003, SOMBASE - Griffiths et al. 2003, 2008, Lovell \& Trego 2003, San Vicente et al. 2007, BAS unpublished data and current study. Some species have been recorded under previous names $\left(^{*}\right)$ and some records $\left(^{\dagger}\right)$ have been considered unlikely.

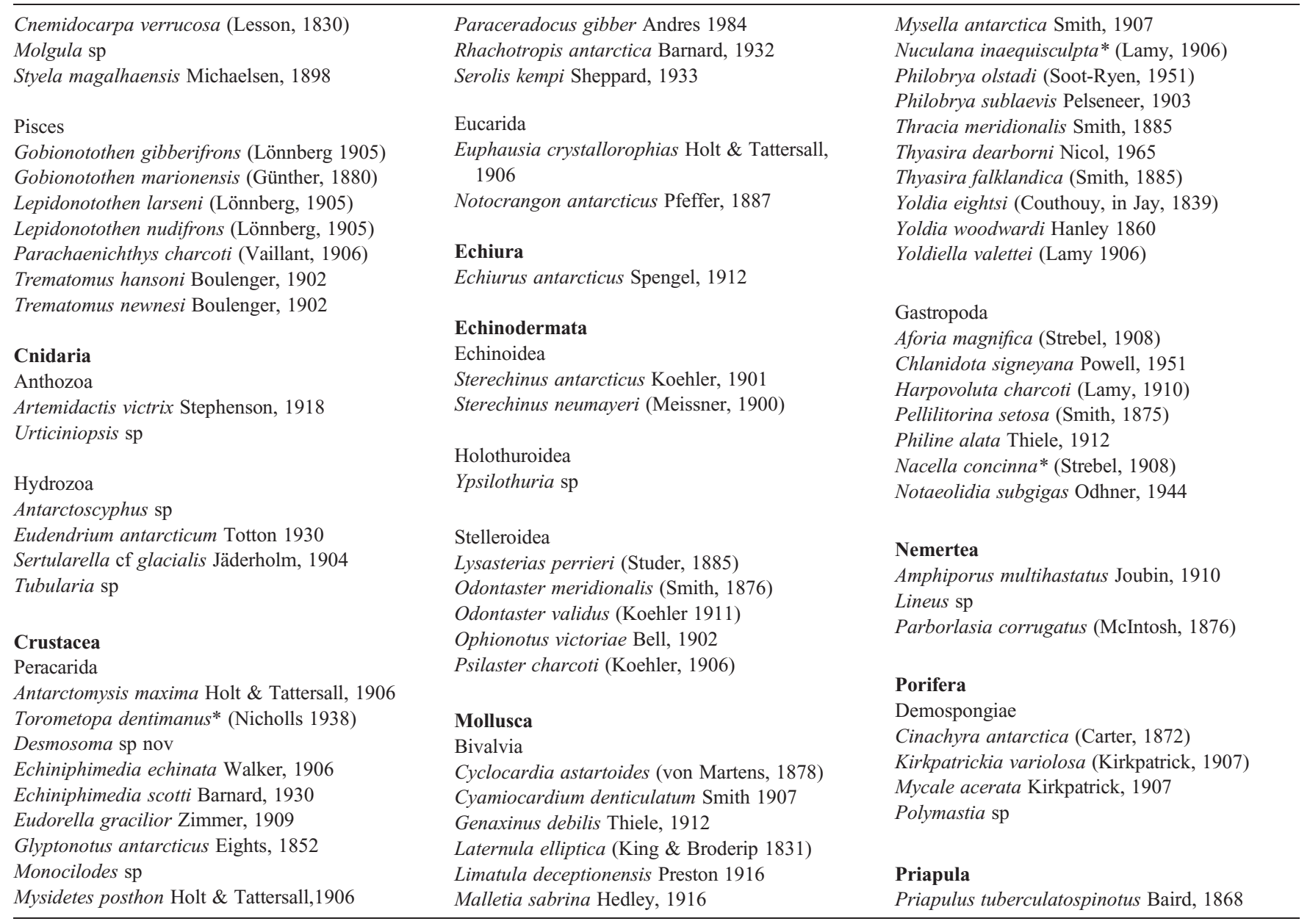

S50 camera in an underwater housing was carried as well as a quadrat of $\sim 0.25 \mathrm{~m}^{2}$. Abundance of mega and macrofauna was semi-quantitatively scored as occurring as units, tens or hundreds per quadrat for five randomly placed quadrats on each transect. Thus $1.25 \mathrm{~m}^{2}$ was surveyed in detail at each depth at each site but more than $100 \mathrm{~m}^{2}$ at each was also coarsely surveyed. Boulders and other substrata were dislodged and macroalgae examined to inspect cryptofauna. Some pebbles containing surface cryptofauna was collected and examined under binocular microscope in order to make genus and species level identifications.

\section{Analysis}

The richness data (number of taxa) and semi-quantitative abundance data were compared between sites (separately for each of the two depths) using non-parametric KruskalWallis tests.

\section{Results}

All taxa were identified to family level and, apart from serpulid polychaetes and lyssianasid amphipods, to genus level. No faunal NIS were found at any site. The three main subtidal areas of Deception Island examined, differed considerably in terms of macro- and megafaunal abundance, richness, dominant taxa and patchiness. Richness and abundance both increased with depth at each site (Kruskal Wallis all $\mathrm{H}_{1}>4.6, P<0.032$ ). Although our samples are not enough to confirm it, we believe that there is a gradient from the channel (Neptune's Bellows) to the caldera interior (Fumarole Bay). From the channel into the caldera at the shallowest study depth both richness and abundance decreased significantly (Kruskal Wallis both $\mathrm{H}_{3}>11.3, P<0.01$ ), with median values falling by two orders of magnitude.

Macro- and megafaunal abundance at Neptune's Bellows was around tens of individuals per $0.25 \mathrm{~m}^{2}$ at $3 \mathrm{~m}$ depth 


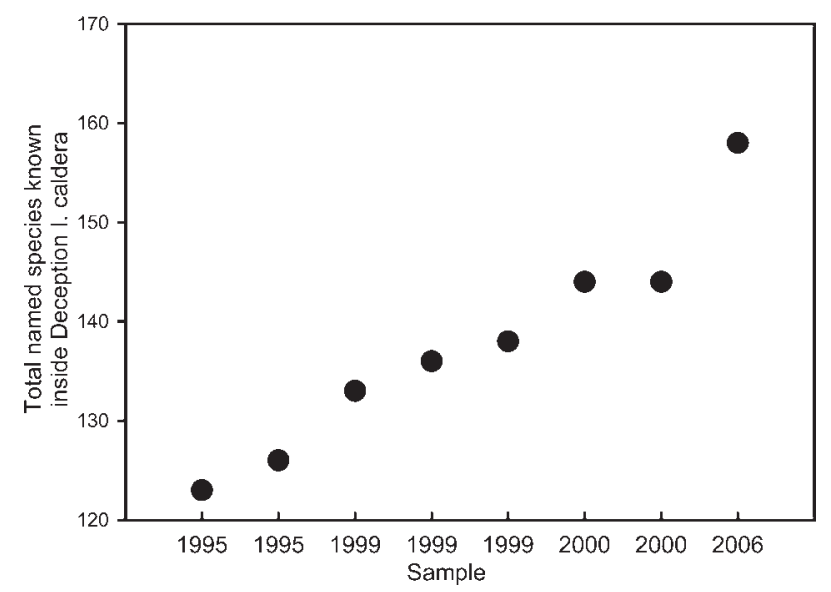

Fig. 3. Total number of species known from Deception Island caldera from recent studies with sample date. Data from comparing recent studies of San Martin et al. (2000), Cranmer et al. (2003), Lovell \& Trego (2003) and current study to older literature.

increasing to hundreds of individuals at $8-11 \mathrm{~m}$ depth. The observed epifaunal community comprised at least 35 species representing 13 classes and 10 phyla (Table I). The dominant fauna and degree of space occupation varied considerably over spatial scales of metres. The upper surfaces of boulders were poorly colonized by fauna (mainly the limpet Nacella concinna) but bryozoans and polychaetes dominated the undersurfaces (cryptofauna). Demosponges, ascidians, cnidarians and their predators (Fig. 2a) dominated the few areas where there were vertical or overhanging surfaces. Notably, echinoderms were not particularly abundant.

Only $200 \mathrm{~m}$ from Neptune's Bellows inside the caldera at Whaler's Bay, only N. concinna was abundant at $3 \mathrm{~m}$ depth and cryptofauna were absent from boulder undersurfaces. Lyssianasid amphipods were the only other macro- or megafauna (patchily) seen. At $8-12 \mathrm{~m}$ depth the epifaunal community was comprised of $\sim 98 \%$ echinoderms (Fig. 2), dominated by the ophiuroid Ophionotus victoriae which occurred at tens of individuals per $0.25 \mathrm{~m}^{2}$. The echinoid Sterechinus neumayeri and the sea star Odontaster validus were occasional in small clusters. In total, only five species, representing four classes and three phyla, were seen during two dives at different locations within Whaler's Bay. Overall abundance and richness appeared an order of magnitude lower than in Neptune's Bellows.

Abundance and richness levels at Fumarole Bay were considerably lower than in Whaler's Bay. At $3 \mathrm{~m}$ no macroor megafauna was obvious. Deeper at $6 \mathrm{~m}$ only lyssianasid amphipods were common associated with boulders and macro-algae with a few scattered $S$. neumayeri individuals. A few small Rhodophyta macroalgae were the only other obvious macroscopic organisms observed.

\section{Discussion}

There are few places around the coast of Antarctica where the nearshore shelf faunas are as well described as at Deception Island. Only in the shallows of the bays of King George Island, Anvers Island, Ryder Bay (in Adelaide Island) and McMurdo Sound, are the fauna as well described, but at all of these sites there have been decades to years of detailed SCUBA work on the shallow fauna. Even around such bays where there are Antarctic research stations we could not find a fauna as well known as at Deception Island for a defined area. This is because whilst many taxa were well recorded, some had been hardly considered e.g. polychaetes at Ryder Bay and that the geographical and bathymetric area surveyed for each taxon varied in extent around bays. Thus, other than at Deception Island, meaningful across taxa, species accumulation curves could not be plotted except for the shallows.

The inventory of macro- and mega-benthos in the shallows of Deception Island generated by the current study were highest at the entrance and lowest in the interior (Table I) but we appreciate that establishment of this as a true gradient would require considerably more samples. The narrow entrance, Neptune's Bellows, has a relatively rich community for its depth (see Dayton 1990, Arntz et al. 1994, Barnes 2000 for comparative data). This is probably due to the combination of moderately high flow rates and the shallow sill restricting ice scouring. The fauna list for Neptune's Bellows lists 14 species not previously recorded from Deception Island (e.g. Paralaeospira aggregata and Arachnopusia inchoata) but the presence of these new species is unsurprising as they are well known from the immediate region (see e.g. Knight-Jones \& Knight-Jones 1984, Hayward 1995). The dives in Whaler's Bay and Fumarole Bay revealed no new records of species but suggested a strong decline of species richness from Neptune's Bellows into the caldera at subtidal depth.

Comparison of Deception Island benthic sampling literature reveals another probable gradient in space, an increase in richness with depth. Data from the literature (Cranmer et al. 2003, Lovell \& Trego 2003) is difficult to compare with the current findings because of differing methodologies and sample effort. Many of the species described from deeper than the subtidal are quite obvious, e.g. large species such as Laternula elliptica and Colossendeis megalonyx. Had they been present at the sites we surveyed it is likely divers would have seen them. However, previous SCUBA dives in Whaler's Bay have recorded 'worms' (probably Parborlasia corrugatus Fig. 2a) and occasional ascidians (Trotter 2006) that we did not see. Trotter (2006) however, found that Remotely Operated Vehicle (ROV) dives revealed little obvious change in benthic communities from SCUBA depths to $80 \mathrm{~m}$.

Richness and abundance have increased at Deception Island with time since the 1969-1970 eruptions (Gallardo 
\& Castillo 1968, 1970, Gallardo et al. 1975, 1977, Retamal et al. 1982, Arnaud et al. 1998, Cranmer et al. 2003, Lovell \& Trego 2003). Whilst the fauna has recovered considerably from these locally devastating impacts, Lovell \& Trego (2003) show that the benthos of Deception is impoverished at species level compared to nearby islands. Furthermore whole classes, such as the anthozoans and holothuroids, are missing and others, such as the gastropods, cephalopods, stelleroids and echinoids, are very poorly represented. In many cases the taxa that have managed to recolonize, for example, within the gastropods and echinoderms, are those with planktotrophic larvae (see Stanwell-Smith et al. 1999). On shorter time scales Cranmer et al. (2003) and Lovell \& Trego (2003) found relatively little monthly or seasonal variability in species presence and abundance, and we suggest that our findings in the current study would probably vary little along similar time scales.

\section{How many species are there at Deception Island?}

Estimating total faunal or metazoan richness has been attempted for terrestrial biota on a number of sub-Antarctic and Antarctic islands (e.g. Gaston et al. 2001). A recent effort on a similar scale to the current study yielded 14 terrestrial faunal species on Deception Island but the total reported at that time was 57 species (Downie et al. 2000). In the Southern Ocean generally, the vast majority of known species, locally or regionally, occur in the sea on the continental shelf. Attempts (such as the Census of Antarctic Marine Life - CAML) are being made to catalogue Antarctic marine species and so estimate the number of species in the Southern Ocean (see Clarke \& Johnston 2003). However, many areas, e.g. the Amundsen Sea, are very poorly sampled and probably nowhere has been sampled to the intensities in terrestrial studies. Deception Island is one of the more sampled sites for its geographic area and thus represents one of the best opportunities at estimating the total number of marine species present in a particular area. In four dives we found a total of 34 species and, together with named species we found reference to in the literature, 163 named species are known to be present (Table II). However, this refers only to benthos and even on the seabed meiofauna and microbes have hardly been investigated. The reported presence of two species of Philobrya, P. olstadi by SootRyen (1951) and P. sublaevis by Lovell \& Trego (2003), might be caused by the morphological similarity and plasticity of the adult shell. The prodissoconch patterns have to be investigated to confirm species identification. The extent to which this is an underestimate of currently known benthic species richness can also be estimated. In addition to the 163 named species, there are phyla and classes (e.g. Nematoda and Calcarea respectively), which are known to occur in the caldera but for which no species names have yet been reported. Across the literature we found reference to unknown morphospecies of at least five annelids, one cnidarian, 33 crustaceans (four mysid, 20 amphipod, two cumacean, five isopod and two euphausid), two nemerteans, one nematode, one sipunculan and seven sponges (e.g. see Cranmer et al. 2003, Lovell \& Trego 2003, San Vicente et al. 2007). This adds a minimum of 50 species waiting to be named to the current total of 163 named species, thus giving a minimum estimate of 2131 species found to date, none of which have been identified as NIS. Some taxa are clearly undersampled or have been sampled but appear under-represented as species await description or recognition. For example, the many nematodes found by various studies, such as the recent BIOPEARL cruise (BAS unpublished data) are likely to comprise more than one species but how many will be unknown until they receive attention by specialist taxonomists. Despite Deception Island being one of the most intensely sampled small areas in the Southern Ocean, new species are still being recorded. Of course some of these may be genuinely new arrivals recolonizing from previous local eruption-related extinction events. The current study added $7.6 \%$ of species to the total number of species known but was the first detailed epifaunal survey of a previously little studied depth (the shallows). New future surveys will undoubtedly increase the total, indeed at least one new species is currently in description from an epibenthic sledge sample taken in the caldera after our SCUBA samples (S. Kaiser personal communication 2007). Species accumulation from recent samples seems to be consistently increasing (Fig. 3) and the number of marine mega- and macro-species may reach 300 .

This first estimate of a total number of marine species present in the Deception Island caldera area is probably considerably lower than would be found in comparative areas around the Southern Ocean for a number of reasons. Assemblage level studies have shown adjacent areas in the South Shetland archipelago are much richer for some taxa while some taxa seem to be almost entirely absent from Deception Island (Finger 1975, Gallardo et al. 1977, Saiz Salinas et al. 1997, San Martin \& Pararpar 1997, San Vicente et al. 1997, 2007, Arnaud et al. 1998, Lörz \& Brandt 2003, Lovell \& Trego 2003). The history of disturbance by volcanism, current extreme sedimentation and temperature regimes, acidity, trace metals and rarity of three-dimensional structures provided by suspension feeding communities (Cranmer et al. 2003 recorded just a few sponges) amongst other factors combine to cause the paucity of taxa at Deception Island. Equivalent Deception caldera-sized areas on the shelf of the Antarctic Peninsula probably have three or four times as many macrofaunal species. To make comparisons meaningful though sampling in other areas needs to be of comparable intensity, area and depth - which is frequently not the case. Nevertheless it seems the small areas of the seabed in the 
Southern Ocean, even those with the physical extreme conditions of Deception Island, can still be extremely rich at species and high taxonomic levels.

\section{Acknowledgements}

The authors would like to thank the officers and crew of RRS James Clarke Ross for aid with SCUBA operations and Dr Igor Smirnov, Huw Griffiths and Stefanie Kaiser for help with species names and lists. Finally we would like to thank Prof Lloyd Peck and three anonymous referees for comments leading to an improved manuscript.

\section{References}

Arnaud, P.M., Ramos-Espla, A.A., Ramos, A., Lopez, C.M., Olaso, I. \& RAmIL, F. 1998. Semi-quantitative study of macrobenthic fauna in the region of the South Shetland Islands and the Antarctic Peninsula. Polar Biology, 19, 160-166.

Arntz, W.E., Brey, T. \& Gallardo, V.A. 1994. Antarctic zoobenthos. Oceanography and Marine Biology, 32, 241-304.

BARNES, D.K.A. 2000. Diversity, recruitment and competition on island shores at south polar localities compared with lower latitudes: encrusting community examples. Hydrobiologia, 440, 37-44.

Barnes, D.K.A., Hodgson, D.A., Convey, P., Allen, C.S. \& Clarke, A.C. 2006. Incursion and excursion of Antarctic biota: past, present and future. Global Ecology and Biogeography, 15, 121-142.

Chevreux, E. 1913. Amphipodes. Deuxième Expédition Antarctique Française (1908-1910) commandée par le Dr. Jean Charcot. Sciences naturelles Documents Scientifiques, 2, 79-186.

Child, C.A. 1994. Antarctic and subantarctic Pycnogonida 1. The family Ammotheidae. Antarctic Research Series, 63, 1-49.

Child, C.A. 1995a. Antarctic and subantarctic Pycnogonida III. The family Nymphonidae. Antarctic Research Series, 69, 1-68.

Child, C.A. 1995b. Antarctic and subantarctic Pycnogonida V. The families Pycnognidae, Phoxichilidiidae, Endeididae, and Callipallenidae, including the genus Pallenopsis. Antarctic Research Series, 69, 113-160.

Clarke, A. \& Johnston, N. 2003. Antarctic marine benthic diversity. Oceanography and Marine Biology, 41, 47-114.

Clayton, M.N., Wiencke, C. \& Klöser, H. 1997. New records and subAntarctic marine benthic macroalgae from Antarctica. Polar Biology, 17, $141-149$.

Cranmer, T.L., Ruhl, H.A., Baldwin, R.J. \& Kaufmann, R.S. 2003. Spatial and temporal variation in the abundance, distribution and population structure of epibenthic megafauna in Port Foster, Deception Island. Deep-Sea Research II, 50, 1821-1842.

DAYton, P.K. 1990. Polar benthos. In Sмith, W.O., ed. Polar oceanography. San Diego, CA: Academic Press, 631-685.

Downie, R.H., Convey, P., McInnes, S.J. \& Pugh, P.J.A. 2000. The nonmarine invertebrate fauna of Deception Island (Maritime Antarctic): a baseline for a comprehensive biodiversity database. Polar Record, 36, 297-304.

ELDERFIELD, H. 1972. Iron, manganese and silicon in waters of Deception Island. British Antarctic Survey Bulletin, No. 30, 103-108.

Finger, K.L. 1975. Benthic foraminifera from Deception Island. Antarctic Journal of the United States, 10(4), 134-135.

Frenot, Y., Chown, S.L., Whinam, J., Selkirk, P., Convey, P., Skotnicki, M. \& Bergstrom, D. 2005. Biological invasions in the Antarctic: extent, impacts and implications. Biological Reviews, 80, 45-72.

Gallardo, V.A. \& Castillo, J.G. 1968. Mass mortality in the benthic infauna of Port Foster resulting from the eruptions in Deception Island,
(South Shetland Islands). Publicaciones Instituto Antartico Chileno, 16, 1-11.

Gallardo, V.A. \& Castillo, J.G. 1970. Quantitative observations on the benthic macrofauna of Port Foster (Deception Island) and Chile Bay. (Greenwich Island). In Holdgate, M.W., ed. Antarctic ecology. London: Academic Press, 242-243.

Gallardo, V.A., Castillo, J.G., Retamal, M.A., Hermosilla, J. \& Trucco, R. 1975. Benthic community studies in the South Shetland Islands. Antarctic Journal of the United States, 10(4), 135.

Gallardo, V.A., Castillo, J.G., Retamal, M.A. \& Yañes, A. 1977. Quantitative studies on the soft-bottom macrobenthic animal communities of shallow Antarctic bays. In Llano, G.A., ed. Adaptations within Antarctic ecosystems. Washington, DC: Smithsonian Institution, 361-387.

Gaston, K.J., Chown, S.L. \& Mercer, R.D. 2001. The animal species-body size distribution on Marion Island. Proceedings of the National Academy of Sciences of the USA, 98, $14493-14496$.

Griffiths, H.J., Linse, K. \& Crame, J.A. 2003. SOMBASE - Southern Ocean Mollusc Database: a tool for biogeographic analysis in diversity and ecology. Organisms Diversity and Evolution, 3, 207-213.

Griffiths, H., Linse, K. \& Barnes, D.K.A. 2008. Distribution of macrobenthic taxa across the Scotia Arc, Southern Ocean. Antarctic Science, 20, 213-226.

Hayward, P.J. 1995. Antarctic Cheilostomatous Bryozoa. Oxford: Oxford University Press, $355 \mathrm{pp}$.

Knight-Jones, P. \& Knight-Jones, E.W. 1984. Systematics, ecology and distribution of southern hemisphere spirorbids (Polychaeta; Spirorbidae). In Hutchings, P.A., ed. Proceedings of the First International Polychaete Conference, Sydney, Australia, July 1983. Sydney: The Linnean Society of New South Wales, 197-210.

Lewis, P.N., Bergstrom, D.M. \& Whinam, J. 2006. Barging in: a temperate marine community travels to the subantarctic. Biological Invasions, 8, 787-795.

LÖRZ, A.-N. \& BRANDT, A. 2003. Diversity of peracarida (Crustacea, Malacostraca) caught in a suprabenthic sampler. Antarctic Science, 15, 433-438.

Lovell, L.L. \& Trego, K.D. 2003. The epibenthic megafaunal and benthic infaunal invertebrates of Port Foster, Deception Island (South Shetland Islands Antarctica). Deep-Sea Research II, 50, 1799-1819.

Moyano, G.H.I. 1978. Bryozoa de Bahias Antarticas: algunos aspectos ecologicos. Serie Cientifica, 24, 35-60.

Olaso, I., Garcia-Castrillo, R.G. \& Balguerias, G.E. 1997. Ichthyofauna of Livingstone and Deception Islands. Boletin de la Real Sociedad Espanola de Historia Natural, 93, 79-86.

Retamal, M.A., Quintana, R. \& Neira, F. 1982. Analisis cuali y cuantitativo de las comunidades bentonicas en Bahýa Foster (Isla Decepcion) (XXXV Expedicion Antartica Chilena, enero 1981. Publication Instituto Antarctico Chileno Series Cientica, 29, 5-15.

Sáiz-Salinas, J.I., Ramos, A., García, F.J., Troncoso, J.S., San Martin, G., SAnz, C. \& Palacin, C. 1997. Quantitative analysis of macrobenthic softbottom assemblages in South Shetland waters (Antarctica). Polar Biology, 17, 393-400.

SAn Martin, G. \& PARAPAR, J. 1997. "Errant”" polychaetes of the Livingston Island shelf (South Shetlands, Antarctica), with the description of a new species. Polar Biology, 17, 285-295.

San Martin, G., Parapar, J., Garcia, F.J. \& Redondo, M.S. 2000. Quantitative analysis of soft bottoms infaunal macrobenthic polychaetes from South Shetland Islands (Antarctica). Bulletin of Marine Science, 67, 83-102.

San Vicente, C., Ramos, A., Jimeno, A. \& Sorbe, J.C. 1997. Suprabenthic assemblages from South Shetland Islands and Bransfield Strait (Antarctica): preliminary observations on faunistical composition, bathymetric and near-bottom distribution. Polar Biology, 18, 415-422.

San Vicente, C., Castelló, J., Corbera, J., Jimeno, A., Munilla, T., Sanz, M.C., Sorbe, J.C. \& Ramos, A. 2007. Biodiversity and structure of the suprabenthic assemblages from South Shetland Islands and Bransfield Strait, Southern Ocean. Polar Biology, 30, 477-486. 
Smith, R.I.L. 1996. Introduced plants in Antarctica: potential impacts and conservation issues. Biological Conservation, 76, 135-146.

Smith JR, K.L., Baldwin, R.J., Kaufmann, R.S. \& Sturz, A.A. 2003. Ecosystem studies at Deception Island, Antarctica: an overview. DeepSea Research II, 50, 1595-1609.

Soot-Ryen, T. 1951. Antarctic Pelecypoda. Scientific Results of the Norwegian Antarctic Expedition 1927-1928, 32, 1-146.

Stanwell-Smith, D., Peck, L.S., Clarke, A., Murray, A.W.A. \& Todd, C.D. 1999. The distribution, abundance and seasonality of pelagic marine invertebrate larvae in the maritime Antarctic. Philosophical Transactions of the Royal Society of London, B353, 1-14.

Tavares, M. \& Melo, M.E.S. 2004. Discovery of the North Atlantic spider crab Hyas araneus (Linneaus, 1758) in the Antarctic Peninsula. Antarctic Science, 16, 129-131.

ThatJe, S. \& Fuentes, V. 2003. First record of anomuran and brachyuran larvae (Crustacea: Decapoda) from Antarctic waters. Polar Biology, 26, 279-282.

Trotter, L. 2006. Below freezing, the Antarctic dive guide. Maidenhead: WildGuides Ltd, UK. 